\title{
Photoperiodic Response of Genetically Diverse Lettuce Accessions
}

\author{
William Waycott ${ }^{1}$ \\ U.S. Agricultural Research Station, U.S. Department of Agriculture, Agricultural Research Service, 1636 \\ East Alisal St., Salinas, CA 93905
}

Additional index words. Lactuca sativa, daylength, temperature, bolting, rapid flowering

\begin{abstract}
A series of experiments was undertaken to study daylength-mediated control of transition to flowering in lettuce (Lactuca sativa L.), a quantitative long-day plant. Several genotypes (cultivars, landraces, and mutant lines) were grown at different photoperiods, sometimes in combination with different temperatures, and measured for number of days to either a) bolting initiation (a detectable increase in the rate of stem elongation) or b) anthesis of the first flower (a standard measure of maturity in lettuce). Experiments were conducted in controlled or partially controlled environments. Results of these studies indicate the following: a) high temperature alone is not sufficient to induce the bolting response, whereas photoperiod is; b) there is a range of genetic responses to various daylengths among lettuce genotypes; c) one of the genes known to control bolting initiation, gene Z', exhibited reverse dominance in conjunction with the Early Flowering genes, depending on the length of day. The latter observation implies the genetic role of $T$ needs further investigation, as it does not appear to operate by simple dominance alone.
\end{abstract}

The transition from vegetative to reproductive growth in lettuce is reported to be mediated by photoperiod (Bremer, 193 1; Rappaport and Wittwer, 1956; Wiebe and King, 1985). Lettuce is a summer annual, a cumulative long-day plant that flowers without vernalization. Visually, the transition to flowering in lettuce begins with accelerated and sustained rapid elongation of the stem (collectively known as bolting). Often during unseasonable weather this process occurs prematurely and plants begin bolting sooner than anticipated, which can render a commercial crop unusable.

Definitive daylength studies performed in highly controlled environments were reported by Ellis et al. $(1988,1989)$ and Roberts, et al. (1988) using barley (Hordeum vulgare L.). Similar to lettuce in its environmental growth requirements, long-day flowering of this annual was shown to have a linear relationship between photoperiod and the reciprocal of the time taken to flower. The authors also found that barley exhibited photoperiodic response limits. At $\leq 10 \mathrm{~h}$, plants were further delayed in flowering, while at $\geq 16 \mathrm{~h}$, there was no increase in response.

The nature of apical meristem control of growth in rosette plants during transition to reproductive growth has been studied by Besnard-Wibaut et al. (1981, 1989). By investigating meristems of Arabidopsis thaliana and Silene armeria, they were able to enumerate the different phases of plant development based on cell division patterns. They concluded that these species have juvenile, intermediate, and adult phases of growth in preparation for flowering and that only during the later phases can an exogenous stimulus (in their case, gibberellin) induce premature flowering.

Photoperiodic studies in lettuce were first reported by Bremer (1931), who grew two so-called long-day cultivars (adapted to winter conditions) and two so-called day-neutral cultivars (adapted to summer conditions) under several daylengths by manipulating light and darkperiods in the field. As in the barley studies, he found the response by long-day cultivars to be linear and inversely

Received for publication 16 Dec. 1994. Accepted for publication 9 Jan. 1995. With gratitude-to Edward Ryder for his generosity and goodwill to Salvador Placencia, Bert Robinson, Steven Vasquez, and Sharon Kimmell for their assistance. I thank Brent Tisserat for a review of this manuscript. Part of this research was supported by the California Iceberg Advisory Board. The cost of publishing this paper was defrayed in part by the payment of page charges. Under postal regulations, this paper therefore must be hereby marked advertisement solely to indicate this fact. 'Current address: Petoseed Co., 650 Lemma Dr., Arroyo Grande, CA 93420. proportional to increases in daylength. Plants bolted as early as 53 days under 18-h days and as late as 112 days under $6 \mathrm{~h}$ of light per day. In contrast, the response by day-neutral cultivars was unaffected by daylength and occurred within a range of 64 to 75 days, regardless of the treatment. When the two types (long-day and dayneutral of lettuces) were crossed, the long-day response was dominant and segregated 3:1 in $\mathrm{F}_{2}$. The segregating trait was designated $T$ for tag neutral, the recessive allele of which did not respond to long photoperiods. Bremer's results were supported by Wiebe and King (1985) who found that winter lettuce cultivars exhibited a strong photoperiodic response, while summer cultivars showed a weak response.

Rappaport and Wittwer (1956), using lettuce greenhouse studies, reported that long days (as well as seedling vernalization and higher temperatures) decreased the number of days to bolting. They found that treatments such as vernalizing (low) and high temperatures and long days were additive and, as the age increased, the influence of high temperatures on bolting became increasingly important.

Ryder (1988) reported the existence of two genes that initiate early transition to bolting and flowering in lettuce ( $E f-1$ and $E f-2$ ). These genes for early flowering exhibited incomplete dominance, where $E f-1$ was dominant over $E f-2$ and the effect of $E f-1$ was shown to be considerably stronger than that of $E f-2$. The number of days to first flower was reduced from 140 to 45 days with both dominant alleles of each gene (Ef-1 Ef-1 Ef-2 Ef-2) and to 50 days with both dominant alleles of one gene (Ef-1 Ef-1 ef-2 ef-2) under greenhouse conditions during long days. The use of these genes was recommended in lettuce breeding as a means of reducing generation time. Rousos (1988) reported that certain strains of these early flowering mutant lines, when grown in controlled environments (growth chamber) under various daylength and temperature regimes, did not respond to high-temperature treatments, but proceeded to flower normally.

Here, a series of studies was undertaken to characterize the effects of daylength and temperature on floral initiation among a group of genotypes from diverse origins: cultivars, breedinglines, and landraces (lines that evolved through selection before the evolution of traditional plant breeding). PhotoPeriodic parameters for several of these accessions were determined and some hypotheses were developed on genetic systems mediating the flowering response. 
Table 1. Average stem height, $\pm \mathrm{SD}$, of plants grown in growth chambers under 8 -h days and high temperatures (daily average $\approx 24 \mathrm{C}$ ) (Study A).

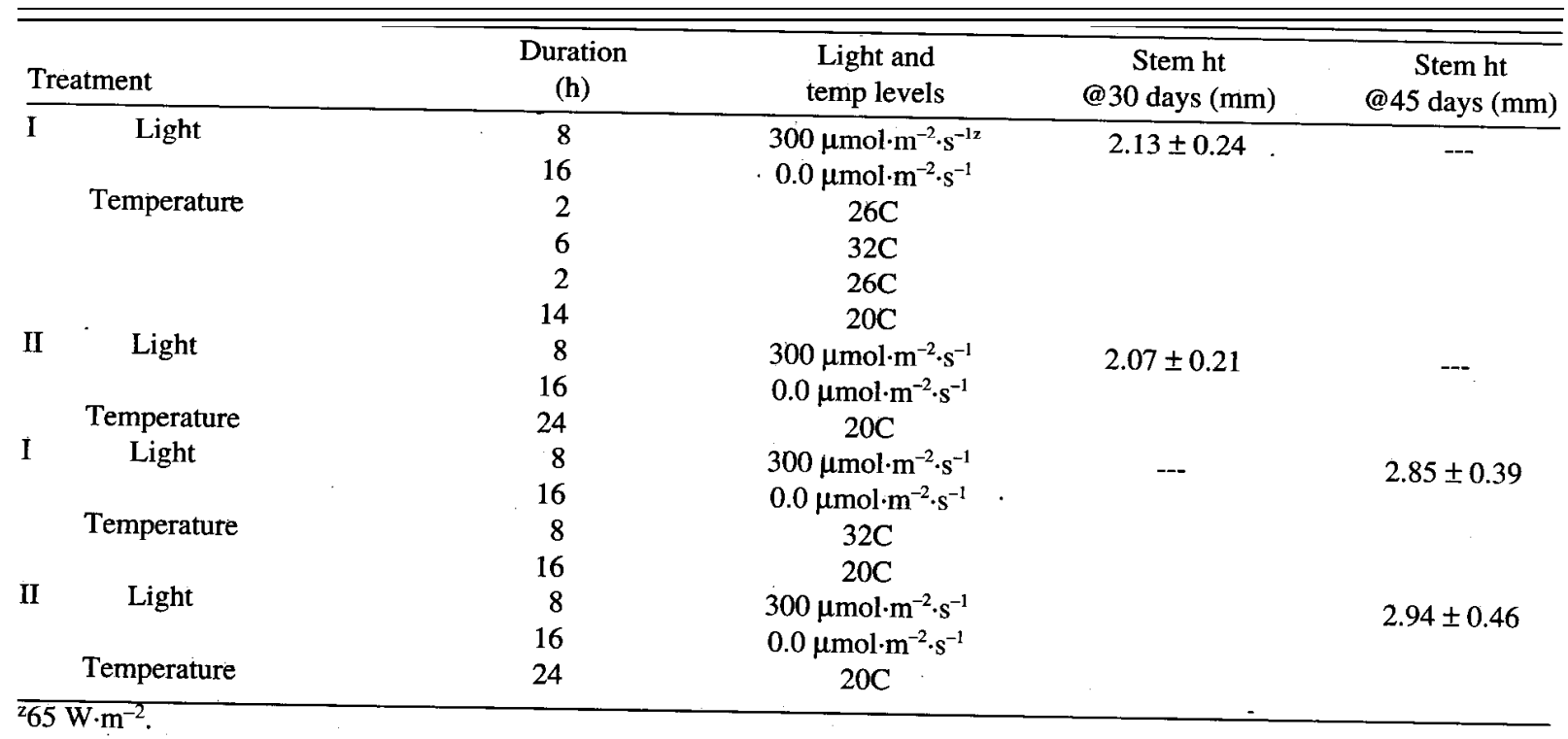

\section{Materials and Methods}

Photoperiodic studies were carried out as a series of experiments between 1984 and 1993 in either growth chambers or greenhouses. Seeds were sown directly into plastic pots $(10 \times 10$ $\times 10-\mathrm{cm}$ ) containing field soil [except in Study B, in that circular clay pots (height $30 \mathrm{~cm}$ top diameter $25 \mathrm{~cm}$ ) were used] and were treated with $\approx 200 \mathrm{ml}$ of fertilizer solution $[20 \mathrm{~N}-8.7 \mathrm{P}-17.7 \mathrm{~K}$ (Peters Fertilizer Products, Fogelsville, Pa.)] at a concentration of $300 \mathrm{mg} \mathrm{N} / \mathrm{liter}$, every week. In all cases, seedlings were thinned to a single plant 2 weeks after sowing.

Experiments conducted in growth chambers (Controlled Environments, Asheville, N.C.) were programmed on a 24-h cycle; irradiance was set at a PPF of $300 \mu \mathrm{mol} \cdot \mathrm{m}^{-2} \cdot \mathrm{s}^{-1}\left(65 \mathrm{~W} \cdot \mathrm{m}^{-2}\right)$. Outer leaves of late maturing cultivars were removed at later stages of growth to reduce crowding in growth chambers and to eliminate potential infection by Botrytis cinerea.

Greenhouse studies were conducted at U.S. Department of Agricultural-Agricultural Research Service facilities in Salinas, Calif. (lat. $36^{\circ} 40^{\prime}$ north, long. $121^{\circ} 40^{\prime}$ west.) under ambient light with maximum daily temperatures $\leq 35 \mathrm{C}$ and minimum nightly temperatures $\geq 18 \mathrm{C}$. Temperatures and irradiance varied as per weather conditions.

In all experiments, five plants of each line were grown simultaneously in a random design, measurements were taken, and means and standard deviations were calculated. The only exception was in Study E in which two flats of 20 plants per each $\mathrm{F}_{3}$ family were grown in a random design. All growth chamber experiments were repeated in a different chamber after the first test had been completed. Five separate studies were conducted as follows:

Effect of high temperature on bolting during short days (Study A). This study was undertaken to confirm that high temperatures in the absence of a photoperiod longer than $12 \mathrm{~h}$ are insufficient to induce bolting during the early (seedling and rosette) stages of growth. Lettuce plants 'Salinas' were grown in growth chambers under 8-h daylengths. In Group I (high-temperature treatment), plants were grown in a stepwise temperature sequence between 20 and 32C (Table 1). In Group II (low-temperature treatment), plants were grown at 20C for $24 \mathrm{~h}$. Stem height was measured at 30 days and again after another 15 days. The experiment was terminated at 45 days (within $\approx 5$ days of market maturity) and its results were used to design later studies.

Effect of natural long and short days on bolting (Study B). This study was undertaken to determine the range of bolting tendency among important cultivars used commercially in California. Five commercial crisphead cultivars ( 'Climax', 'Empire', 'Montemar', 'Salinas', and 'Vanguard 75') from various regions of adaptation were sown in the greenhouse during either the first week of January (daylengths ranged from 8 to $14 \mathrm{~h}$ ) or the first week of July (daylengths ranged from 14 to $8 \mathrm{~h}$ ), and the number of days needed to attain a stem height of $15 \mathrm{~cm}$ was measured. These results were used to formulate subsequent experiments.

Effect of artificial long, medium, and short days on bolting (Study C). This study was undertaken to determine the effect of five photoperiods on a diverse range of plant types. Several cultivars, breeding lines, and landraces of lettuce known to have different daylength responses were grown in growth chambers at 8-, 10-, 13-, 16-, and 20-h photoperiods with the same PPF, with a temperature regime of $25 \mathrm{C}$ for the first $8 \mathrm{~h}$ of the daylight period and $10 \mathrm{C}$ for the remaining hours. Lines used in this study and in subsequent studies were either dominant or recessive for the gene or $T$ [dominant allele of $T$ causes early bolting under long day conditions, (Bremer, 1931)].

The lines used included a) two butterhead cultivars, from Europe known to express the dominant $T$ allele 'May King' and 'Saffier', b) an Egyptian landrace 'Balady', c) two plant introductions (PIs) from the USDA collection known for their rapid flowering character (PI 175735 and PI 250020), d) four crisphead cultivars from North America from various regions of adaptation, with the recessive $t$ allele ('Empire', 'Fairton', 'Salinas', 'Valtemp'), and e) four lines (E-1, E-3, E-7, and E-9) from the early flowering group of mutants with various maturities and a different genetic basis for control of bolting (Ef-1, Ef-2) (Ryder, 1988).

Effect of very long days on bolting (Study D). This study was undertaken to examine in more detail the 20-h photoperiod results in Study C. Thirteen fast flowering lines were grown along with the Early Flowering mutants in two environments: a) a rapid growth environment (continuous $25 \mathrm{C}, 20$-h photoperiod) and b) a natural long day environment $(\approx 14 \mathrm{~h}$, sown 29 Mar.) in the greenhouse. 


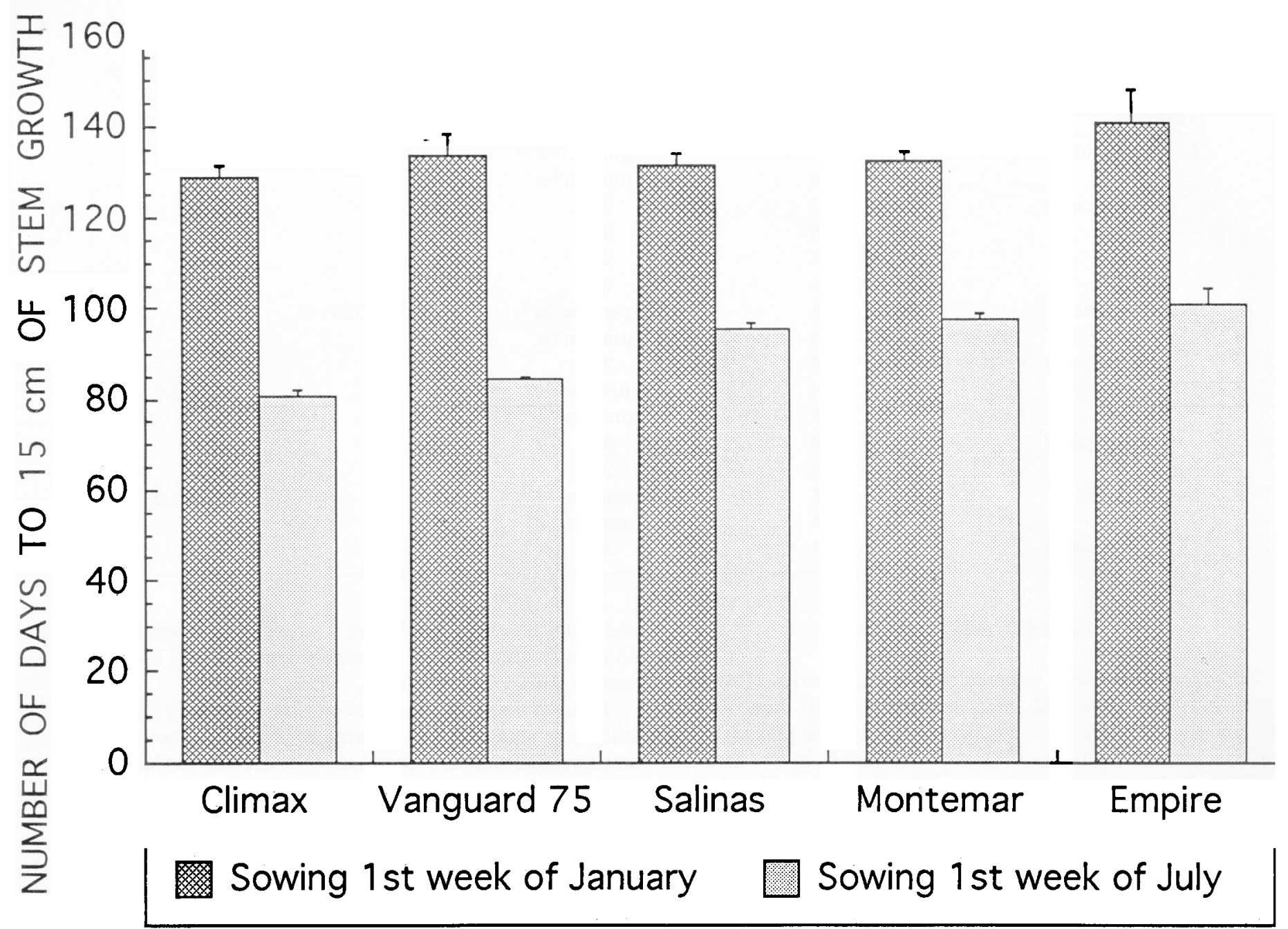

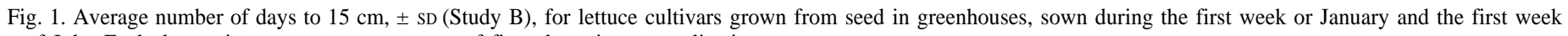
of July. Each data point represents an average of five plants in two replications.

These lines included the same set of lines used in Study C, except that the crisphead lines were replaced with nine other rapid flowering PI lines (175735, 184113, 190906, 202439, 204753, $250020,251245,251798$, and 253229). All of these lines had been shown to bolt early in previous work (unpublished data).

Effect of natural long and short days on different bolting systems (Study E). This study was undertaken to measure the response of plants known to have $E f$ and/or $T$, genes which control bolting induction by accelerating its initiation under certain environmental conditions. A set of $111 \mathrm{~F}_{3}$ families from the cross dwarf-2 x 'Saffier' were grown in the greenhouse and measured for the mean number of days to first flower per family. The genes

Table 2. Average number of days to $15 \mathrm{~cm}, \pm \mathrm{SD}$ (Study C) for genotypes grown from seed in growth chambers at specific daylengths and identical temperatures. Each data point represents an average of five plants in two replications.

\begin{tabular}{lccccc}
\hline & \multicolumn{5}{c}{ Light per day $(\mathrm{h})$} \\
\cline { 2 - 6 } Name & 20 & 16 & 13 & 10 & 8 \\
\hline Balady & $41.3 \pm 1.5 \mathrm{f}^{2}$ & $58.5 \pm 3.8 \mathrm{~g}$ & $92.3 \pm 3.1 \mathrm{e}$ & $112.4 \pm 2.4 \mathrm{c}$ & $123.8 \pm 4.9 \mathrm{e}$ \\
Empire & $90.3 \pm 0.3 \mathrm{~b}$ & $91.1 \pm 0.6 \mathrm{c}$ & $108.2 \pm 9.7 \mathrm{c}$ & $115.2 \pm 2.1 \mathrm{c}$ & $136.3 \pm 4.5 \mathrm{~cd}$ \\
Fairton & $102.5 \pm 1.6 \mathrm{a}$ & $107.2 \pm 0.8 \mathrm{~b}$ & $158.3 \pm 4.1 \mathrm{a}$ & $163.7 \pm 7.8 \mathrm{a}$ & $177.3 \pm 1.8 \mathrm{a}$ \\
Salinas & $72.2 \pm 10.3$ & $69.7 \pm 3.4 \mathrm{~d}$ & $105.6 \pm 12.1 \mathrm{c}$ & $113.7 \pm 1.8 \mathrm{c}$ & $132.6 \pm 4.7 \mathrm{~d}$ \\
May King & $48.4 \pm 0.6 \mathrm{e}$ & $68.3 \pm 0.7 \mathrm{~d}$ & $99.5 \pm 4.3 \mathrm{~d}$ & $118.9 \pm 7.8 \mathrm{c}$ & $138.2 \pm 1.8 \mathrm{c}$ \\
Saffier & $41.5 \pm 2.1 \mathrm{f}$ & $64.7 \pm 1.4 \mathrm{e}$ & $89.4 \pm 3.5 \mathrm{e}$ & $115.2 \pm 6.3 \mathrm{c}$ & $135.7 \pm 3.7 \mathrm{~d}$ \\
Valtemp & $60.3 \pm 2.3 \mathrm{~d}$ & $127.8 \pm 12.5 \mathrm{a}$ & $141.7 \pm 3.3 \mathrm{~b}$ & $158.1 \pm 2.8 \mathrm{a}$ & $176.7 \pm 7.6 \mathrm{ab}$ \\
PI 250020 & $21.1 \pm 0.4 \mathrm{i}$ & $31.8 \pm 0.7 \mathrm{i}$ & $35.4 \pm 2.1 \mathrm{~h}$ & $50.7 \pm 3.9 \mathrm{f}$ & $52.5 \pm 2.5 \mathrm{~h}$ \\
PI 175735 & $27.7 \pm 0.3 \mathrm{~h}$ & $37.8 \pm 0.2 \mathrm{~h}$ & $58.6 \pm 3.7 \mathrm{f}$ & $66.4 \pm 8.6 \mathrm{e}$ & $78.5 \pm 1.1 \mathrm{f}$ \\
E-1 & $33.6 \pm 0.3 \mathrm{~g}$ & $36.5 \pm 2.7 \mathrm{~h}$ & $41.6 \pm 0.6 \mathrm{~g}$ & $42.2 \pm 0.7 \mathrm{~g}$ & $50.2 \pm 1.4 \mathrm{~h}$ \\
E-3 & $52.3 \pm 3.9 \mathrm{e}$ & $55.2 \pm 2.9 \mathrm{~g}$ & $60.4 \pm 1.8 \mathrm{f}$ & $61.1 \pm 3.4 \mathrm{e}$ & $69.8 \pm 5.3 \mathrm{~g}$ \\
E-7 & $60.6 \pm 0.4 \mathrm{~d}$ & $61.2 \pm 1.3 \mathrm{f}$ & $91.7 \pm 7.1 \mathrm{e}$ & $89.6 \pm 9.3 \mathrm{~d}$ & $119.4 \pm 2.8 \mathrm{e}$ \\
E-9 & $100.1 \pm 2.5 \mathrm{a}$ & $120.9 \pm 0.8 \mathrm{a}$ & $138.7 \pm 3.9 \mathrm{~b}$ & $144.2 \pm 8.3 \mathrm{~b}$ & $167.8 \pm 2.6 \mathrm{~b}$ \\
\hline
\end{tabular}

$\overline{{ }^{2} \text { Means within columns followed by the same letter are not significantly different at } P=0.05 \text { by Duncan's multiple range test. }}$ 


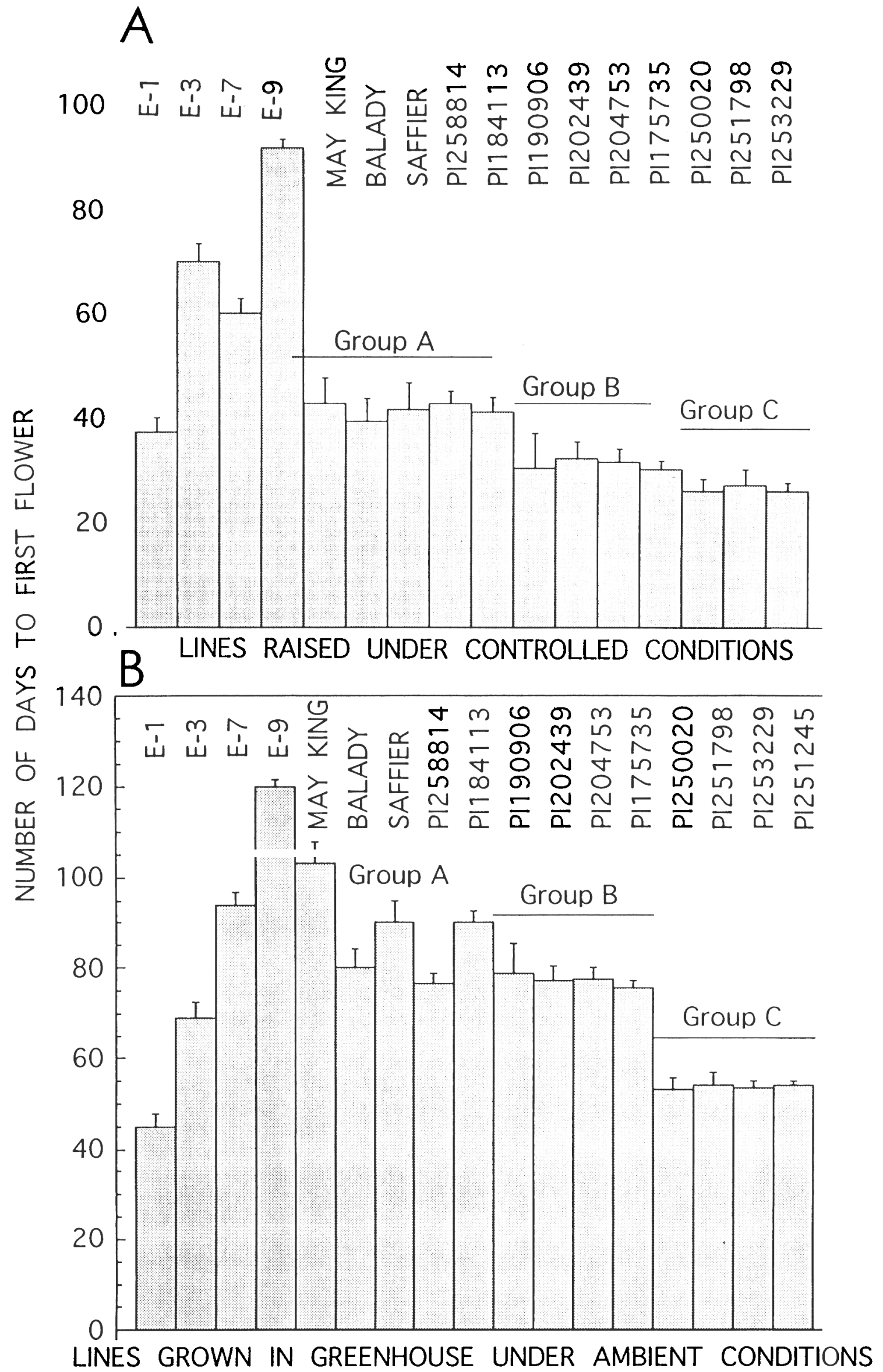

Fig. 3. Average number of days to first flower, \pm SD (Study D), for fast flowering lines grown from seed in growth chambers under 20-h days (A), and grown from seed in greenhouses under long day $(\approx 14 \mathrm{~h})(\mathbf{B})$. Groups A, B, and C represent groupings of lines with similar flowering dates. Each data point represents an average of five plants in two replications. 

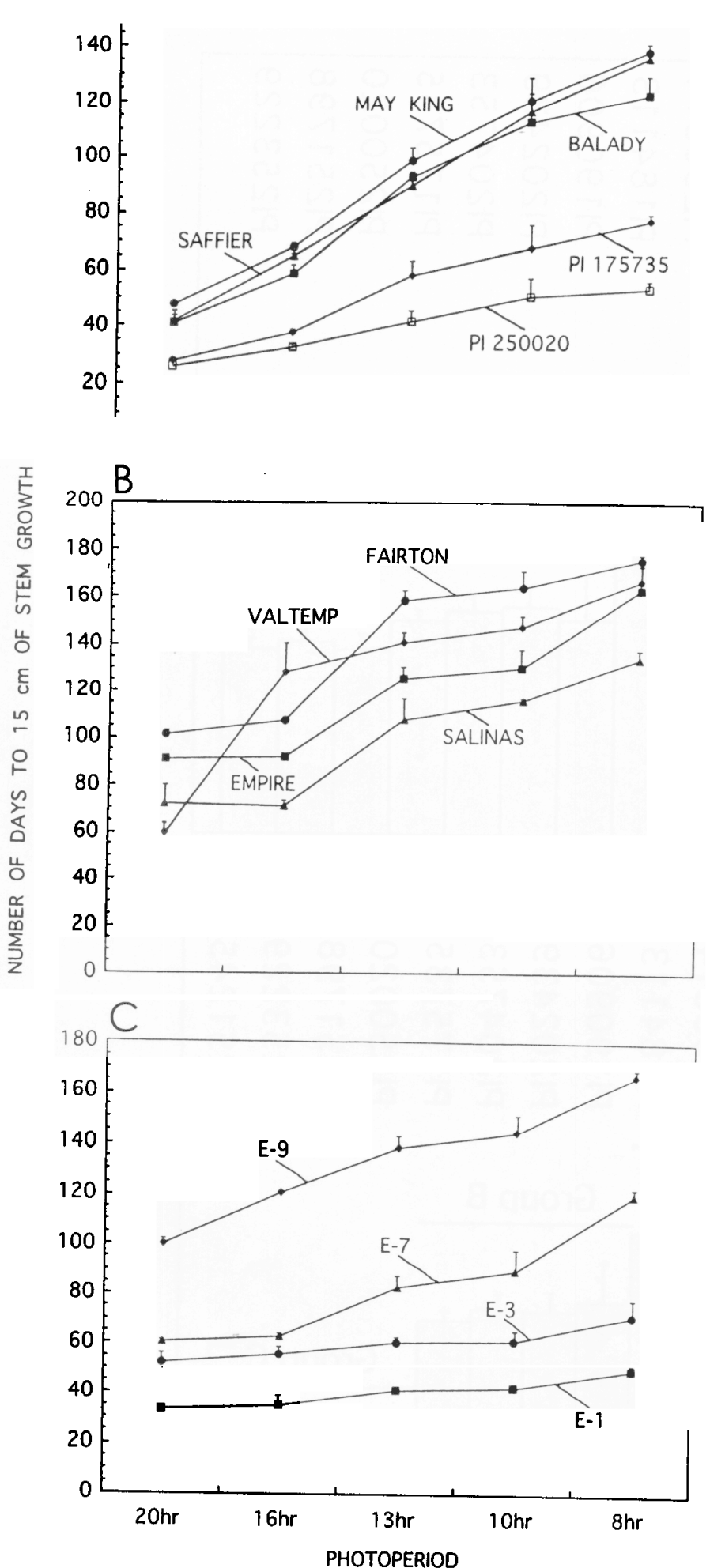

Fig. 2. Average number of days to $15 \mathrm{~cm}, \pm \mathrm{SD}$ (Study C), for various genotypes grown from seed in growth chambers at specific daylengths and identical temperatures. (A) 'Balady' ( $\mathbf{\square})$, 'May King' ( $\mathbf{0}$ ), 'Saffier' ( $\boldsymbol{\Delta}$ ), Plant Introduction (PI) $175735(\bullet)$, and PI 250020 ( 口); (B) 'Empire' ( 口), 'Fairton' ( ○ ), 'Salinas' $(\boldsymbol{\Delta})$, and 'Valtemp' ( $\bullet$ ); and $(\mathbf{C})$ E-1( $\boldsymbol{\bullet})$, E-3( $\bullet$ ), E-7( $\boldsymbol{\Delta})$, E-9( $\bullet$ ). Each data point represents an average of five plants in two replications.

evaluated were: a) $E f-1$, and to a lesser extent $E f$-2 [the effect of $E f$ 1 is known to be considerably stronger than that of $E f-2$ (Ryder 1998), and the ratios described here reflect primarily the effect of $E f-1]$, from the dwarf-2 parent, and b) $T$ from 'Saffier'. These $\mathrm{F}_{3}$ families were grown during natural long days (15 to 12 h, 25 May sowing) and then again under natural short days (from 9 to $12 \mathrm{~h}, 13$ Nov. sowing), and the average of 30 plants in each family was used to calculate earliness.

\section{Results}

Effect of high temperature on bolting during short days (Study A). The cultivar 'Salinas' was grown in two temperature regimes under short day-conditions in growth chambers (Table 1). Group I temperatures were programmed to emulate natural diurnal fluctuation of 20,26, 32, 26, 20C, while Group II temperatures did not change from $20 \mathrm{C}$. After 45 days and within $\approx 5$ days of market maturity under these conditions, stem heights did not exhibit significant differences between treatments and the study was terminated. The design of further experimentation was then predicated on this lack of difference.

Effect of natural long and short days on bolting (Study B). Plants of the five cultivars sown in July started bolting between 80 to 100 days after sowing (Fig. 1), while the same lines sown in January started bolting in 130 to 140 days. Results of the July sowing indicate 'Climax' was the fastest flowering line and 'Empire' was the slowest line. Results of the January sowing showed slight differences in rate of bolting initiation but all lines performed similarly.

Effect of artificial long, medium, and short "days on bolting (Study C). In this study, two European butterheads, one Egyptian stem lettuce, four North American crispheads, and four $E f$ mutant lines were tested under five different daylength conditions in growth chambers (Table 2). Results indicated that responses among lines to the various daylengths were more characteristic among lines with similar genetic backgrounds than with unrelated material. Although not statistically similar in most cases, lines were grouped according to their relative association as depicted by the slopes between data points (Fig. 2).

Lines originating from Europe and Egypt ('May King', 'Saffier', 'Balady') were statistically ranked in the same or adjacent groupings. This relationship is illustrated in Fig. 2A by the slopes between data points (number of days to $15 \mathrm{~cm}$ photoperiod) for each cultivar. A similar pattern, although for plants that bolted much earlier, was observed for PI 175735 and PI 250020. As the number of hours of light per day decreased, the number of days to $15 \mathrm{~cm}$ increased.

Lines developed in North America ('Empire', 'Fairton', 'Salinas', 'Valtemp') were also found to be ranked consistently in adjacent groupings. This relationship is shown in Fig. 2B by slopes between data points for each cultivar. This pattern was characterized by little or no change in response between the 16- and 20-h and the 10- and 13-h treatments. Greater changes were recorded between the 8- and 10- and the 13- and 16-h treatments, except for 'Valtemp', which responded early to the 20-h photoperiod.

The four Early Flowering mutant lines were arranged in a third group (Fig. 2C). These lines exhibited a range of responses to increases in photoperiod. $E-1$ and $E-3$ showed a very slight response over the entire photoperiod range, differing only by a few days for any one treatment. E-7 and E-9 showed a more typical crisphead response, similar to the group depicted in Fig. 2B, from which part of their genome is derived.

The differences in response between E-1 and E-3 on the one hand and the two PIs (175735 and 250020) on the other are clearly illustrated when comparing Fig. $2 \mathrm{~A}$ and C. The former exhibited a slight difference over the range of photoperiods, while the latter showed a greater difference in the response to the same range. 
Table 3. Distribution of averaged first flower dates of individuals in each of $111 \mathrm{~F}_{3}$ families generated from the cross dwarf- $2 \times$ 'Saffier' (Study E).

\begin{tabular}{lccccc}
\hline \hline \multirow{2}{*}{ Photoperiod } & \multicolumn{2}{c}{ No. of families } & Expected & & \\
\cline { 2 - 6 } & Early & Late & ratio & $\chi^{2}$ & $P$ \\
\hline Long days & 90 & 89 & $13: 3$ & 0.06 & $0.90-0.95$ \\
Short days & 30 & 81 & $5: 11$ & 0.21 & $0.50-0.70$ \\
\hline
\end{tabular}

Effect of very long days on bolting (Study D). 'May King', 'Balady', and 'Saffier', and PI 258814 and 184113 flowered $\approx 42$ days after sowing and were designated as Group A (Fig. 3A). A faster group, (PI 190906, PI 202349, PI 204735, and PI 175735) flowered in $\approx 32$ days and was designated as Group B. The fastest group, (PI 250020, PI 251798, and PI 253229) flowered in $\approx 27$ days and was designated as Group C. In this experiment the fastest class, Group C, was characterized by tall, erect plants that bolted without forming a rosette.

In this same study, the Early Flowering lines appeared to maintain a day-neutral response, however the normally faster $E-3$ line [as determined in previous greenhouse tests Ryder 1988], flowered consistently later than $E$-7. The numbers of days to first flower for all Early Flowering lines were similar to values obtained under previous very long-day studies (Fig. 2C).

When these same plants were grown in the greenhouse under long days $(\approx 14 \mathrm{~h})$, they took longer to achieve the same stage of growth compared to the growth-chamber data (Fig. 3B). The Early Flowering mutants flowered in the expected order: $E$ - 1 flowered in $\approx 45$ days and $E-9$ in $\approx 120$ days. The position of genotypes within groups $B$ and $\mathrm{C}$ with respect to each other was unchanged between Fig. $3 \mathrm{~A}$ and $\mathrm{B}$ $(\approx 78$ days and $\approx 55$ days, respectively). However, differences within Group A were detected under these greenhouse conditions. 'May King' took longer to bloom than the others ( $\approx 105$ days), 'Saffier' and PI 184113 bloomed slightly earlier ( $\approx 91$ days), and Balady and PI 258814 flowered earliest ( $\approx 78$ days), similar to Group B plants.

Effect of natural long and short days on different bolting systems (Study E). Averaged first flower dates for individuals in each $\mathrm{F}_{3}$ family were early in about three-fourths of the families when grown under long days $(\approx 15 \mathrm{~h})\left[x^{2}(13: 3)=.06, P=0.90\right.$ 0.95] (Table 3, Fig. 4). However, roughly one-fourth of the same families flowered early when grown under short days $(\approx 9 \mathrm{~h})\left[x^{2}\right.$ $(5: 11)=0.21, P=0.50-0.70]$.

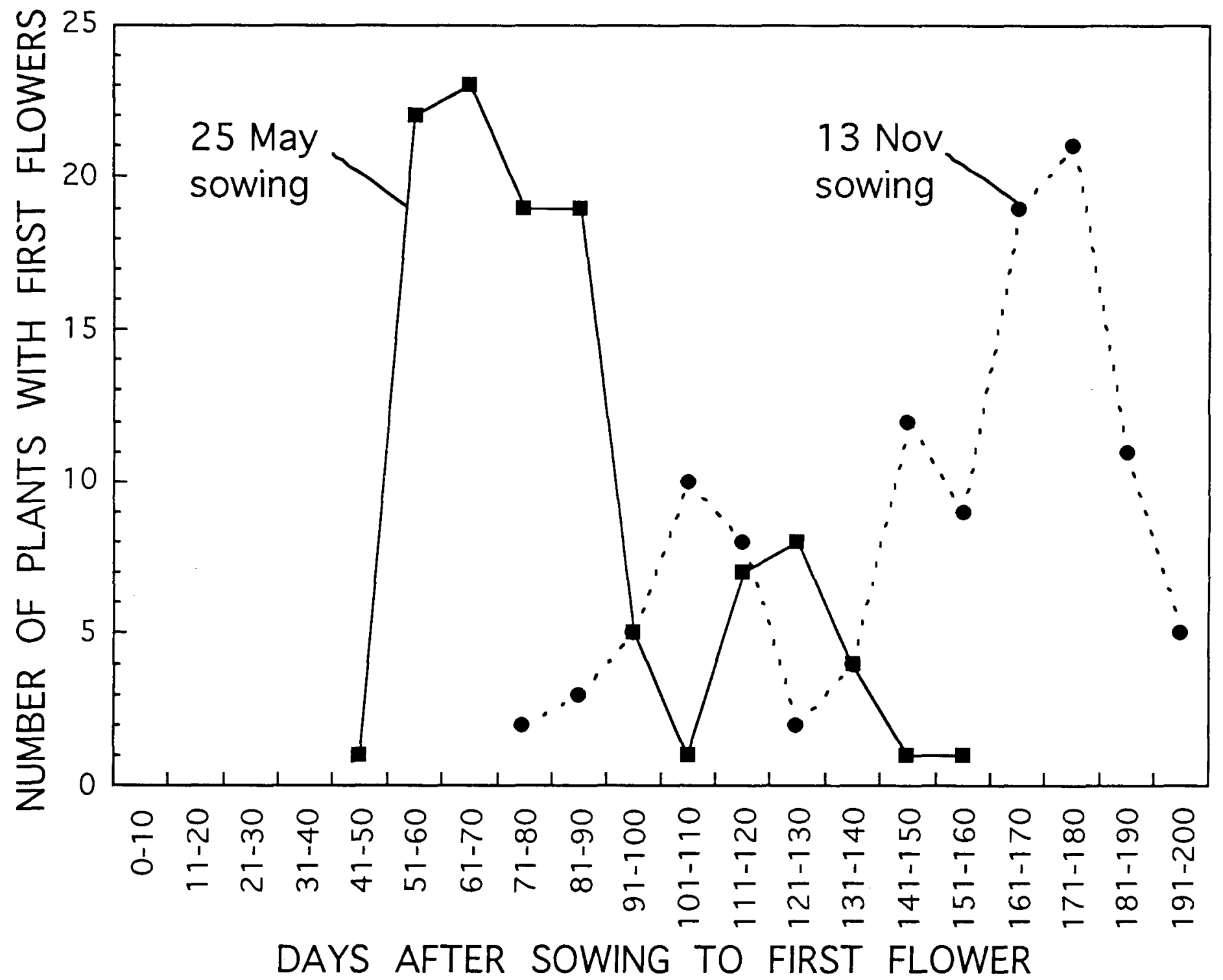

Fig. 4. Sums of $\mathrm{F}_{3}$ family averages (Study E) from the dwarf-2x 'Saffier' cross for mean number of days after sowing to the first anthesis per family for two different dates of sowing; 25 May ( $)$ and 13 Nov. ( ). Each data point represents an average of 20 plants from one family in one replication, 
Table 4. Genotype-phenotype comparison of averaged first flower dates of individuals in $\mathrm{F}_{3}$ families generated from the cross dwarf 2 x 'Saffier' (Study E).

\begin{tabular}{|c|c|c|c|}
\hline \multirow{2}{*}{$\begin{array}{l}\mathrm{F}_{2} \\
\text { genotypes }\end{array}$} & \multirow{2}{*}{$\begin{array}{c}\text { No. and probable } \\
\text { genotypes of } F_{3} \text { families }\end{array}$} & \multicolumn{2}{|c|}{ Earliness phenotypes ${ }^{2}$} \\
\hline & & Long days & Short days \\
\hline$\overline{E E T T}$ & $1-\mathrm{All}$ EETT & Early & Early \\
\hline EETT' & 2-EETT EETT' EET $T^{\prime}(1: 2: 1)$ & Early & Early \\
\hline$E E T^{\prime} T^{\prime}$ & 1-All $E E T^{\prime} T^{\prime}$ & Early & Late \\
\hline$E e T T$ & 2-EETT EeTT eеTT (1:2:1) & Early & Early \\
\hline$E e T T^{\prime}$ & 4-Same as $\mathrm{F}_{2}$ distribution & Early & Late \\
\hline$E e T^{\prime} T^{\prime}$ & 2-EET'T $E T^{\prime} T^{\prime} T^{\prime} e e T^{\prime} T^{\prime}(1: 2: 1)$ & Early & Late \\
\hline$e e T T$ & $1-$ All eeTT & Early & Late \\
\hline$e e T T^{\prime}$ & 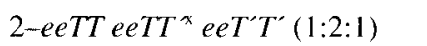 & Late & Late \\
\hline$e e T^{\prime} T^{\prime}$ & 1-All eeT'T & Late & Late \\
\hline
\end{tabular}

${ }^{\overline{ }}$ Represent family averages.

${ }^{y} E$ and e represent alleles of gene $E f-1, T$, and T represent alleles of gene $T$

${ }^{\mathrm{x}}$ This genotype may tend to be late.

\section{Discussion}

The results reported here support the findings by Bremer(1931) that lettuce is a quantitative long-day plant when adequate light quantity and quality and ample growing temperatures are provided. According to Zeevaart (1976), the set of environmental cues leading to the initiation of flowering appear to be different in quantitative long-day plants than in typical short-day (e.g., Chenopodium and Pharbitis) or long-day plants (e.g., Silene and Spinacia), which respond to 1 or 2 days of daylength treatment, or for typical biennials (e.g., Daucus, Apium, and Beta), which require low vernalizing temperatures before bolting.

In previous daylength studies with lettuce, researchers were unable to separate the effects of temperature and daylength because of the technology existing at the time. Thus, it has been widely interpreted that high-temperature is a major cause of bolting in lettuce (Rappaport and Wittwer 1956). By using controlled environments in this study, high temperature effects were minimized so that photoperiod, not temperature, was characterized as the critical mediator of plant growth rate in lettuce. In this case, extremes of temperature, as well as other stresses, appear to mediate the effect of daylength. This finding is supported by the work of Rousos (1988).

Evidence to support this conclusion is borne out by the results of Study A. When grown under short days and high temperatures, plants remained as rosettes during the vegetative phase of growth. During the seedling, rosette, and head formation phases leading up to market maturity, the point at which harvest would have occurred, these plants did not bolt. When heat and long days were given in Study B, bolting was initiated just after the theoretical harvest (80 to 90 days after sowing), thus confirming the role of photoperiod in this process. In contrast, results of Study C indicated 'Valtemp' and 'Fairton' required nearly 6 months to begin bolting when grown in the shortest day treatment $(8 \mathrm{~h})$. The combination of short days and noninducing temperatures still enabled these bolt-tolerant cultivars to continue growing vegetatively until transition to reproductive growth was initiated without the high-temperature stimulus.

These results are related to those of Besnard-Wibaut et al. (1989), who showed that an exogenous stimulus cannot be an initiating factor for bolting during the early phases of rosette plant development. They reported that such a stimulus could only be a factor during the intermediate phase and later. The late response to heat by lettuce was also borne out in the data presented by Bremer
(1931) and Rappaport and Wittwer (1956). It is also observed frequently in the field when high-temperature periods occur during later stages of growth (Waycott 1992).

The data also indicate that there are different photoperiod response systems in lettuce (Studies C, D, and E). According to Bremer ( 193 1), one of the distinctions between summer and winter lettuce cultivars was the expression of the gene $T$. In that study, the wild-type allele caused accelerated bolting during long days; hence, lines with that allele were termed long day cultivars. This cultivar class included the winter lines 'Leppermann' and 'May King' and are exemplified by the European butterheads 'May King' and 'Saffier' (Fig. 2A).

In addition to the long-day types, Bremer termed the summer lettuces in his study as day-neutral cultivars after finding they responded minimally to a range of daylength treatments. He reported that lines such as 'Rudolph's Liebling' and 'Wheeler's Tom Thumb' have the recessive allele of the same gene. The lack of response by these day-neutral types may also be at work in the American crisphead lines used in this study and could be the basis of bolting tolerance found in these cultivars.

However, results of Study C also indicate that Bremer's term 'day neutral' used for the summer cultivars maybe a misnomer since there was a response difference observed between the 13- and 16-h treatments for this class (Fig. 2B). This difference averaged $\approx 40$ days between the two photoperiods, while Bremerreported a difference of only 11 days. Perhaps, cultivars with a high degree of bolting tolerance were not available in those days, hence he would have only detected a narrower range of differences. The term modified long day is perhaps more appropriate in this case. For lettuce to be truly day neutral, a response similar to lines E-1 and E-3 (Study C, Fig. 2C) would be expected.

In addition, results from Study E suggest a different interpretation from that of Bremer with regard to gene $T$ regulation. In this study, $\mathrm{F}_{3}$ families from the cross dwarf-2 $\mathrm{x}$ 'Saffier' produced two distinct ratios of first flower dates with about three-fourths of the plants bolting early under long days and late under short days (Table 3 ). This assessment was based on only one data set, and a more thorough evaluation is needed.

Yet, the ratios reported here suggest the possible occurrence of reverse dominance by gene $T$, where two alleles of equal but opposite effect (T, T') act under the two distinct environments (Table 4), rather than by simple dominance as suggested by Bremer (1931). Theoretically, under long days, all families were early except those descended from plants with genotypes eeTT and eeTT. This would 
suggest an expected ratio of 13 early families : 3 late families, assuming $T$ is partially dominant to $T$ and genotype eeTT tended to be later even during long days. And, under short days, families descended from genotypes EETT, EETT, and EeTT would be early and the remainder late, with an expected ratio of 5 early families :11 late families. The observed populations fit the expected ratios and explain why opposing results were obtained from the same range of genotypes under these diverse conditions. Early bolting in this population did not appear to be regulated by the $E f$ genes, suggesting alleles $T T$ are epistatic to the $E f$ genes.

The very fast-flowering PI lines grown under 20-h photoperiods in Study D (Fig. 3A) flowered as early as 27 days after sowing and exhibited a tight range of responses under these conditions. The margin of separation between Groups B and C was $\approx 4$ days and needs further investigation. The origin of the very fast-flowering lines is not well documented and some of them may in fact be identical. Most of them originated in the eastern Mediterranean basin and they were not likely bred for salad use, but for their rapid stem elongation and seed production (Ismaiel and Nawar 1972; Lindqvist, 1960; Ryder 1979). These plant types exhibited limited rosette growth, and stem elongation began soon after seedling emergence.

These data suggest there is an array of responses to daylength within the lettuce genome, some of which could be used to develop a set of cultivars with different dates of maturity.

\section{Literature Cited}

Bremer, A.H. 1931. Einfluss der Tageslänge auf die Wachstumsphasen des Salats. Genetische Untersuchungen I. Die Gartenbauwissenschaft 4:469-483.

Besnard-Wibaut, C. 1981. Effectiveness of gibberellins and 6benzyladenine on flowering of Arabidopsis thaliana. Physiol. Plant. $53: 205-212$
Besnard-Wibaut, C., T. Cochet, and M. Noin. 1989. Photopenod and gibberellic acid-Control of the cell cycle in the meristem of Silene armeria and its effects on flowering. Physiol. Plant. 77:352-358.

Ellis, R. H., E.H. Roberts, R.J. Summer-field, and J.P. Cooper. 1988. Environmental control of flowering in barley (Hordeum vulgare L.). II. Rate of development as a function of temperature and photoperiod and its modification by low-temperature vernalization. Ann. Bet. 62: 147158.

Ellis, R. H., R.J. Summer-field, E.H. Roberts, and J.P. Cooper. 1989. Environmental control of flowering in barley (Hordeum vulgare L.). III. Analysis of potential vernalization responses, and methods of screening germplasm for sensitivity to photoperiod and temperature. Ann. Bot. 63:687-704.

Ismaiel, M.M. and E.A. Nawar. 1972. Antioxidants and their effect on the stability of lettuce seed oil during storage. Agr. Res, Rev. 50:293-299.

Lindqvist, L. 1960. On the origin of cultivated lettuce. Hereditas 46:319350 .

Rappaport, L. and S.H. Wittwer. 1956. Flowering in head lettuce as influenced by seed vernalization, temperature, and photoperiod. J. Amer. Soc. Hort. Sci. 67:429-437.

Roberts, E. H., R.J. Summerfield, J.P. Cooper, and R.H. Ellis. 1988. Environmental control of flowering in barley (Hordeum vulgare L.). I. Photoperiod limits to long day responses, photoperiod-insensitive phases and effects of low-temperature and short-day vernalization. Ann. Bet. 62:127-144

Rousos, P. 1988. Effects of photopenod and heat on lettuce growth and flowering times. HortScience 23:811 (Abstr.).

Ryder, E.J. 1979. Leafy Salad Vegetables. AVI Publishing Co., Westport, Corm.

Ryder, E.J. 1988. Early flowering in lettuce as influenced by a second flowering time gene and seasonal variation. J. Amer. Soc. Hort. Sci. 113:456-460.

Waycott, W. 1992. Why lettuce bolts. Fine Gardening 26:46.

Wiebe, H.J. and H. King. 1985. Influence of daylength on development and growth of lettuce. Gartenbauwissenschaft 50:202-206.

Zeevaart, J.A.D. 1976. Physiology of flower formation. Annu. Rev. Plant Physiol. 27:321-348. 